\title{
Measuring the Success Level and Effectiveness of Knowledge Management in Organizations: A Case Study
}

\author{
Azin Mesbah \\ Dpt of Information Technology \\ Management, College of \\ Management and Economics, \\ Science and Research Branch, \\ Islamic Azad University, \\ Tehran, Iran.
}

\author{
Mohammadreza Babaei \\ Dpt of Industrial Management \\ College of Management and \\ Accounting, Yadegar-e-Imam \\ Khomeini (RAH), Shahre Rey \\ Branch, Islamic Azad University \\ Tehran, Iran
}

\author{
Alireza Shabanali \\ Faculty of Management \\ Department of Management \\ University of Tehran \\ Tehran, Iran
}

\begin{abstract}
Knowledge management is a systematic approach to improve organizational ability to mobilize knowledge and facilitate decision-making in setting business strategy. This study identifies the outcomes of an effectively implemented knowledge management in one of the departments of 'Iran Khodro' as an empirical case study. Effective factors on effectiveness of knowledge management and effective outcomes of knowledge management were extracted by a semi-structured interview in three questions with 20 experts. Then, results of interviews and the factors extracted from literature were integrated; by removing similar factors, 52 factors were identified and organized in three groups. Using exploratory Delphi analysis in two stages (by expert's judgments), 30 out of $\mathbf{5 2}$ factors extracted from literature and interview were identified as outcomes of knowledge management implemented in the organizations; these factors were evaluated through a second questionnaire in 32 questions for prioritization of their significance in the studied organization by experts and managers. Based on the coefficient calculated for the confirmed factors in three groups of outcomes, the top priority was knowledge, followed by human resourceorganization and performance, respectively. Ranking of the rest is explained below.
\end{abstract}

Keywords-knowledge management; outcomes of effective knowledge management; performance outcomes of knowledge management; knowledge outcomes of knowledge management; model development.

\section{INTRODUCTION}

Currently, any organization needs to acquire, create, store and use knowledge as one of the most important determinants of growth and development [1]. Effective knowledge strategy promotes the organization [2]. According to [3], intellectual capitals account for $60-70 \%$ of the real value of companies. Empirical evidence suggests that this could be the basis for economic growth and development, because competitiveness of companies is not for physical and financial resources, but for quality of human capitals and intellectual capitals as well as quantity and quality of knowledge, innovation, creativity etc.
[4]. In [5], authors addressed knowledge management from the perspective of information technology with two cognitive and social strategies. Many scholars claim that any knowledge management strategy emphasizes two main aspects, i.e. system and human. According to [6], knowledge management refers to optimization of organizational knowledge by using a variety of techniques to achieve greater productivity. Knowledge management is a systematic process for managing knowledge in organizations. In other words, knowledge management can be defined as creation, collection, transfer and employment of knowledge to promote organizational efficiency [7]. Because knowledge plays an important and strategic role in research organizations, it is essential to develop a model to measure effectiveness of knowledge management in these organizations by professionals and experts [8].

Different scholars have suggested different models with a variety of indicators for measuring effectiveness of knowledge management in organizations. For example, a model was presented in [9] with 5 criteria (employees, data, information, knowledge and wisdom) and 30 sub-criteria for measuring effectiveness of organizational knowledge management. It was claimed that the most important problems with development of this model included multiplicity of goals, difficulty evaluation and fuzzy nature of knowledge management which must be overcome. Models to evaluate the performance of knowledge management based on financial and non-financial criteria and critical factors in order to improve quality of knowledge management systems have also been presented [10]. Therefore, the development of a model in which all effective factors on effectiveness and success of knowledge can be considered as ranked by experts of this industry can help a large industrialmanufacturing organization to take advantage of knowledge management and its processes for developing new products, eliminating defects of products to achieve global quality standards, taking advantage of market opportunities, identifying strengths and advantages of rivals, improving and promoting research and development continuously [1]. 
In order to fill the research gap in the field of effective factors on success and effectiveness of knowledge management and their ranking in government industrial organizations such as Iran Khodro, it is essential to develop models which consider all effective factors on effectiveness and knowledge management in organizations. By these models, managers and planners can implement knowledge management in the organization by a full knowledge of factors which guarantee their success in implementing knowledge management in research and operational departments. They can also improve knowledge management processes in departments in which these processes have been already implemented by a full knowledge of these factors and their significance in success of knowledge management. The present study tends to identify components and variables of effectiveness of knowledge management implemented in the organization.

\section{LITERATURE REVIEW}

- Knowledge: knowledge refers to argument on information and data to achieve efficiency, problem solving, decisionmaking, learning and teaching. According to [11], there are two types of knowledge: explicit and implicit. Implicit knowledge involves high levels of expertise and skills; implicit knowledge lacks a distributable structure and a specific form. It is difficult to classify and document implicit knowledge. Explicit knowledge refers to a more realistic and logical form of technical knowledge which can be documented in a distributable form without any need for interpersonal relationships and can be transported with a single process and strategy.

- Knowledge management: knowledge management refers to any process or acts of producing, acquiring, capturing, promoting, socializing and employing knowledge which can increase learning and performance of the organization. Knowledge management is a process through which organizations generate capital from members' ideas and knowledge-based assets. According to [12], knowledge management is a mechanism to create a work environment in which knowledge and expertise are easily distributed and to provide opportunities to distribute knowledge and information at the right time so that people can act effectively and efficiently. In this study, knowledge management operationally refers to creation, searching, sharing and employment of knowledge in one of the departments of Iran Khodro for operational and managerial processes.

- Effectiveness: theoretically, effectiveness of measures taken to achieve goals is predetermined. In simpler words, an effectiveness study measures realization of goals. In other words, effectiveness shows the extent of efforts made to achieve the considered results, while utilization of resources to achieve the results is related to efficiency. In [13] it was stated that effectiveness means doing things right. According to [13] effectiveness is the key to the success of organizations. Operationally, this study uses effectiveness as properly implemented knowledge management in the studied organization in terms of creation, search, employment and sharing of knowledge.
- Key success factors: theoretically, key success factors include a limited number of activities which are followed by successfully competitive performance. In other words, these factors include characteristics, conditions or variables which can have a significant effect on success of competitive position, if properly managed [14]. Studying the role of key success factors in effectiveness of knowledge management in project and temporary organizations, authors in [15] presented four types of factors including knowledge culture (developed networks of knowledge, flexibility in solving problems, senior management commitment), structural factors (inter-department structure), process factors (knowledge control processes and maturity of knowledge processes) and technological factors (communication systems and knowledge storage systems). Through an exploratory analysis of the factors creating success and effectiveness of knowledge management in insurance organizations. In [16], authors identified environmental factors, personal factors in managers and employees, knowledge characteristics in the organization, organizational factors, technological and cultural infrastructures. In [17], authors examined the effectiveness of knowledge management in knowledge-based organizations and concluded that organizational factors, knowledge resources, type of communications, knowledge holding and organization of knowledge repositories and a long-term approach to knowledge management are effective factors on effectiveness of knowledge management.

\section{MATERIALS AND METHODS}

This was an extended qualitative research and a field study. Data was collected by surveying through a valid questionnaire. Semi-structured interview and Delphi analysis were used to identify the most important outcomes of knowledge management in the organization among 20 experts (top managers and experts of Iran Khodro in Tehran who were familiar with the concept of knowledge management as well as university professors who were experts in scientific and practical implementation of knowledge management in organizations). For ranking outcomes of knowledge management identified by experts, TOPSIS analysis was done on responses of experts and 150 managers and experts of a department of Iran Khdro in which the author tended to measure outcomes of knowledge management implemented in that department. Using Cochran's formula, the sample size was reduced to 108:

$$
n=\frac{\frac{z^{2} p q}{d^{2}}}{1+\frac{1}{N}\left(\frac{z^{2} p q}{d^{2}}-1\right)}
$$

where, $\mathrm{N}$ is the size of population; $\mathrm{n}$ is the size of sample; $\mathrm{Z}=1.96 ; \mathrm{q}=50$ and $\mathrm{p}=50 ; \mathrm{d}=0.05$. This was a test and hypothesis study in which hypotheses were tested by using relevant data. To measure and analyze the data obtained, descriptive statistics were used to obtain means and standard deviations of questions and frequency distribution of responses given to each question and histogram in a 5-point Likert scale in both questionnaires 
by using Excel 2010 and SPSS 19. For inferential statistics, weight of factors listed in the first questionnaire was determined by Delphi; multi-criteria decision-making TOPSIS was used to rank the confirmed factors using t-test. To measure reliability of the first questionnaire, Cronbach's alpha was calculated by using SPSS; Table I presents output of this process:

TABLE I. RELIABILITY OF THE VARIABLES RELATED TO THE SECOND QUESTIONNAIRE

\begin{tabular}{|c|c|c|}
\hline Variable & Cronbach's alpha & Number of questions \\
\hline Performance & 0.875 & 12 \\
\hline Knowledge & 0.909 & 11 \\
\hline Human Resource & 0.902 & 9 \\
\hline Total reliability & 0.937 & 32 \\
\hline
\end{tabular}

As shown in the Table I, $\alpha>0.7$ confirmed reliability of the questionnaire; that is, the questions were internally consistent and the responses were given carefully. Thus, the results could be used for statistical analysis. Formal and content validity were used to measure validity of the first and second questionnaires. Before the questionnaires were distributed among the samples, the advisor and supervisor professors were asked to review the questionnaires in terms of the number of questions and their relevance to the subject and content validity. Moreover, they were asked to see whether the measured elements could formally measure the considered concept. The objections to the questions were determined and resolved in the questionnaire; then, formal and content validity of the questions were confirmed by the professors.

\section{RESULTS}

\section{A. Delphi Analysis to Identify the Most Important Outcomes of Knowledge Management}

The first questionnaire was used to identify the most important outcomes of knowledge management through Delphi analysis. According to the analysis, 52 factors identified and given to 20 experts were reduced to 30 factors through two Delphi stages.

\section{1) First Delphi Stage}

The questionnaire with 52 questions (effective factors on effectiveness and outcomes of knowledge management) was distributed among 20 experts and managers. They were asked to express their agreement or disagreement to all 25 questions based on their experiences and knowledge in 5 states of optimality (from very low optimality to very high optimality). Then, the scores were determined by calculating standard deviation of responses (Table II).

According to the results of first Delphi stage, 13 out of 52 factors $(\mathrm{SD}>1.7)$ were discarded:

- Improved emergency management.

- Improved operational procedures.

- Increased efficiency.

- Change management.

- Reengineering processes.

- Flexible and standard knowledge structure.
- Security and protection of knowledge.

- Developed knowledge networks.

- Updated information systems.

TABLE II. RESULTS OF FIRST DELPHI STAGE

\begin{tabular}{|c|c|c|}
\hline Component & Factor & SD \\
\hline 1 & Continuous learning culture & 0.47 \\
\hline 2 & Improved emergency management & 1.89 \\
\hline 3 & Improved specialized marketing processes & 0.11 \\
\hline 4 & Quality management & 0.77 \\
\hline 5 & Improved customer service & 0.82 \\
\hline 6 & Organizational learning & 0.74 \\
\hline 7 & Improved operational procedures & 1.78 \\
\hline 8 & Organizational integration & 0.89 \\
\hline 9 & Innovative products & 0.61 \\
\hline 10 & Leadership in innovation & 0.30 \\
\hline 11 & Increased competitive advantage & 0.74 \\
\hline 12 & Increased efficiency & 1.78 \\
\hline 13 & Increased effectiveness & 0.049 \\
\hline 14 & Efficient innovation & 0.81 \\
\hline 15 & Optimal customer relationship & 0.96 \\
\hline 16 & Increased creativity & 0.04 \\
\hline 17 & Developed technological infrastructures & 0.92 \\
\hline 18 & Change management & 1.87 \\
\hline 19 & $\begin{array}{l}\text { Improved financial and non-financial performance } \\
\text { (organizational performance) }\end{array}$ & 0.41 \\
\hline 20 & Reengineering processes & 1.89 \\
\hline 21 & Flexible problem solving & 0.11 \\
\hline 22 & R\&D and its success & 0.77 \\
\hline 23 & Organizational research & 0.89 \\
\hline 24 & Knowledge creation & 1.42 \\
\hline 25 & Knowledge conversion & 1.39 \\
\hline 26 & Flexible and standard knowledge structure & 1.85 \\
\hline 27 & Knowledge localization & 0.49 \\
\hline 28 & $\begin{array}{l}\text { Facilitated knowledge acquisition (discussion and } \\
\text { interaction) }\end{array}$ & 0.63 \\
\hline 29 & Formulated knowledge strategies & 0.49 \\
\hline 30 & Modeling strategy and effective knowledge structure & 0.83 \\
\hline 31 & Knowledge classification & 1.10 \\
\hline 32 & Security and protection of knowledge & 1.91 \\
\hline 33 & Developed knowledge networks & 1.80 \\
\hline 34 & Organized knowledge repositories & 0.45 \\
\hline 35 & Organizational learning & 0.49 \\
\hline 36 & New knowledge production & 0.53 \\
\hline 37 & Updated information systems & 1.71 \\
\hline 38 & Standardized procedures & 1.5 \\
\hline 39 & Employee participation and learning & 1.12 \\
\hline 40 & New ideas of employees & 1.79 \\
\hline 41 & Team work and participation & 0.63 \\
\hline 42 & Knowledge empowerment of managers & 0.45 \\
\hline 43 & Human resource development & 1.65 \\
\hline 44 & Focus on organizational needs & 1.42 \\
\hline 45 & Expert knowledge and motivation & 0.99 \\
\hline 46 & Non-resistance to technology & 1.84 \\
\hline 47 & Knowledge-based vision and mission & 1.31 \\
\hline 48 & $\begin{array}{c}\text { Improved organizational structure and reduced } \\
\text { concentration (flexible structure) }\end{array}$ & 1.90 \\
\hline 49 & $\begin{array}{l}\text { Evaluation of readiness and current level of } \\
\text { knowledge management in organizations }\end{array}$ & 1.63 \\
\hline 50 & $\begin{array}{l}\text { Incentive measures for staff particularly creative and } \\
\text { innovative staff }\end{array}$ & 0.79 \\
\hline 51 & $\begin{array}{c}\text { Spiral and flexible career paths within the } \\
\text { organization, especially for knowledge forces }\end{array}$ & 1.90 \\
\hline 52 & $\begin{array}{l}\text { Open and flexible communication with environment } \\
\text { and competitors }\end{array}$ & 1.16 \\
\hline
\end{tabular}


- New ideas of employees.

- Non-resistance to technology.

- Improved organizational structure and reduced concentration (flexible structure).

- Spiral and flexible career paths within the organization, especially for knowledge forces.

2) Second Delphi Stage

The rest 39 factors were evaluated by experts more strictly $(\mathrm{SD}=1)$; thus, 9 other factors were discarded. Finally, 30 factors remained for further analysis. The discarded factors included:

- Improved organizational structure and reduced concentration (flexible structure).

- Flexible problem solving.

- Knowledge localization.

- Facilitated knowledge acquisition (discussion and interaction).

- Organized knowledge repositories.

- Organizational learning.

- Optimal customer relationship.

- Increased creativity.

- Developed technological infrastructures.

Finally, 30 out of 52 factors extracted from literature and interviews were identified as outcomes of knowledge management implemented in the organization. These 30 factors were ranked through the second questionnaire by the experts using TOPSIS.

3) T-test for Presence or Absence of the Determined Factors by Delphi Analysis

Two hypotheses $\mathrm{H}_{1}$ and $\mathrm{H}_{0}$ were considered for each of 32 factors determined in the second questionnaire. $\mathrm{H}_{0}$ assumed that the factor was not effective on effective outcomes of knowledge management and $\mathrm{H}_{1}$ assumed that the factor was effective on effective outcomes of knowledge management. Since $\mathrm{H}_{0}$ was accepted (sig<0.05), the factors $2,3,4,5,7,8,9$, $10,12,13,14,15,16,20,22,23,24,25,26,28,29$ and 31 were effective. Therefore, following factors were considered as effective outcomes of knowledge management implemented in the studied organization.

- Growth of market processes.

- In this organization, management is concerned with quality management processes in the field of quality of products and manufacturing processes.

- Management commitment to implementation of quality standards and monitoring of implementation.

- Management considers customer needs and gathers information about them.

- Integration exists in processes (production and support).

- Management considers product innovation in terms of quality and design.

- Innovations are used to improve market performance.

- Mechanisms are defined for sharing information between different departments.

- Value creation is improved for customer relying on knowledge gained from customers and the market.

- Financial performance is improved in terms of sales and net profit.
- Management considers increase in research in the organization to improve performance.

- Adequate budget is allocated for research for improving products and services.

- The organization considers knowledge creation through discussion and teamwork.

- Classification of knowledge related to customer needs and their availability.

- Management emphasizes staff training and research encouragement.

- Procedures and guidelines of various processes are standardized.

- Employee participation in decision-making

- Management facilitates teamwork and participation among employees.

- Empowerment of operational management and training

- Awareness of organizational needs regarding customers, suppliers, employees and processes.

- This organization considers knowledge of workers and motivates them to apply their knowledge in their jobs.

- Encouragement of creative and innovative staff.

Since sig $>0.05$ for the factors $1,6,11,17,18,19,21,27,30$ and 32 , the hypothesis on equal lower and upper bounds of the considered strict effectiveness (3.5) was not rejected; moreover, $\mathrm{H}_{0}$ was accepted because the upper bound was smaller. Therefore, the following factors were not considered as effective outcomes of knowledge management implemented in the studied organization.

- Lack of concern for organizational learning and turn it into a strategy for management.

- Not using external environment to learn more information about production processes and performance improvement.

- Sharing information of processes among departments which have failed to increase effectiveness of production and products.

- Lack of attention to conversion of implicit experience of experienced staff to information available to all employees, particularly new employees.

- Lack of attention to redeployment of activities of competitors to improve processes.

- Lack of attention to acquiring knowledge of customers by their feedback and inclusion of their feedback in production processes.

- Unavailability of knowledge related to competitors and their products and their movements in the automotive market.

- Lack of attention to empowerment of employees for challenging jobs.

- Lack of emphasis on learning in mission and vision.

- Lack of good and effective communication with rival firms and external environment.

\section{B. Ranking of Effective Outcomes of Knowledge Management by TOPSIS}

Out of 32 factors identified as effective outcomes of knowledge management, 22 factors were extracted from t-test as the most important outcomes of knowledge management. 
This section ranks these 22 factors by using TOPSIS, as follows:

\section{1) Normalization of Decision Matrix}

To compare the scores given based on a 5-point Likert scale from very low optimality (1) to very high optimality (5), the decision matrix of given scores was normalized to a weighted unscaled matrix by using the Euclidean norm. Each number in the column was divided by the root square sum of the numbers in that column. Mathematically, this can be written as:

$$
n_{i j}=\frac{a_{i j}}{\sqrt{\sum_{i=1}^{m} a_{i j}^{2}}}
$$

Thus, judgments of 108 experts were extracted in three groups (performance, knowledge, and human resource organization) and then normalized.

$$
\begin{aligned}
& A^{*}=\left\{\left(\max _{i} \nu_{i j} \mid j \in J\right),\left({\left.\operatorname{m~} \underset{i}{\text { in }} \nu_{i j} \mid j \in J^{\prime}\right\}}_{A^{*}}=\left\{\nu_{i}^{*}, \nu_{2}^{*}, \ldots, \nu_{n}^{*}\right\}\right.\right. \\
& A^{-}=\left\{\left(\min _{i} \nu_{i j} \mid j \in J\right),\left(\max _{i} \nu_{i j} \mid j \in J^{\prime}\right\}\right. \\
& A^{-}=\left\{\nu_{1}^{-}, \nu_{2}^{-}, \ldots, \nu_{n}^{-}\right\}
\end{aligned}
$$

2) Calculation of Distance of Any Alternative from PIS and NIS

This section determines the distance of any factors from positive ideal solution (PIS) and negative ideal solution (NIS) by using following formula:

$$
\begin{aligned}
& S_{i}^{*}=\sqrt{\sum_{j=1}^{n}\left(\nu_{i j}-\nu_{j}^{*}\right)^{2}} \\
& S_{i}^{-}=\sqrt{\sum_{j=1}^{n}\left(\nu_{i j}-\nu_{j}^{-}\right)^{2}}
\end{aligned}
$$

Table III lists the results related to distance of factors from PIS and NIS.

TABLE III. THE RESULTS RELATED TO DISTANCE OF FACTORS FROM POSITIVE AND NEGATIVE IDEALS

\begin{tabular}{|c|c|c|c|}
\hline & Factor & Distance from PIS & Distance from NIS \\
\hline 1 & Performance & 1.948709 & 0.274707 \\
\hline 2 & Knowledge & 0.526325 & 1.768677 \\
\hline 3 & $\begin{array}{c}\text { Human resource - } \\
\text { organization }\end{array}$ & 0.724977 & 1.691601 \\
\hline
\end{tabular}

3) Calculation of Closeness of Any Factor to PIS and NIS

This section determines closeness (CL) which is equal to minimum alternative distance divided by sum of minimum alternative distance and ideal alternative distance. CL was calculated by following formula. The results are listed in Table IV.

$$
C L_{i}^{*}=\frac{d_{i}^{-}}{d_{i}^{-}+d_{i}^{+}}
$$

TABLE IV. CLOSENESS OF FACTORS TO PIS AND NIS AND FINAL RANKING

\begin{tabular}{|c|c|c|}
\hline Factor & CL & Rank \\
\hline Performance & 0.123552 & 3 \\
\hline Knowledge & 0.770665 & 1 \\
\hline Human resource -organization & 0.699999 & 2 \\
\hline
\end{tabular}

Based on CL calculated for factors of each class of outcomes, the outcomes can be ranked in a descending form. In this regard, the top ranked outcome is knowledge, followed by human resource -organization and performance. Note that, the above stages were performed for all factors separately.

\section{Ranking of Performance Outcomes Using TOPSIS}

Following steps were taken to rank performance outcomes by using TOPSIS:

- Normalization of decision matrix.

- Calculation of PIS and NIS.

- Calculation of distance of any alternative from PIS and NIS.

- Calculation of closeness of any factor to PIS and NIS.

Based on CL calculated for 10 performance outcomes, the top ranked factor was considerable improvement of financial performance and the last factor was improvement of performance by innovation (Table V and Table VI).

TABLE V. DISTANCE OF FACTORS FROM PIS AND NIS

\begin{tabular}{|c|c|c|c|}
\hline & Performance outcomes & $\begin{array}{c}\text { Distance } \\
\text { from PIS }\end{array}$ & $\begin{array}{c}\text { Distance from } \\
\text { NIS }\end{array}$ \\
\hline 1 & Growth of marketing processes & 1.687797 & 1.633763 \\
\hline 2 & Attention to quality management & 2.260535 & 1.104352 \\
\hline 3 & $\begin{array}{c}\text { Management commitment to quality } \\
\text { standards }\end{array}$ & 2.221774 & 1.179989 \\
\hline 4 & Attention to customer needs & 2.307012 & 0.974596 \\
\hline 5 & $\begin{array}{c}\text { Integration of processes (production } \\
\text { and support) }\end{array}$ & 2.451424 & 0.779589 \\
\hline 6 & Innovation in quality and design & 2.445249 & 0.800397 \\
\hline 7 & $\begin{array}{c}\text { Improvement of performance by } \\
\text { innovation }\end{array}$ & 2.480419 & 0.697787 \\
\hline 8 & $\begin{array}{c}\text { Correct information sharing } \\
\text { mechanism }\end{array}$ & 0.623792 & 2.529572 \\
\hline 9 & $\begin{array}{c}\text { Superiority over competitors by value } \\
\text { creation for customers }\end{array}$ & 0.60855 & 2.543649 \\
\hline 10 & $\begin{array}{c}\text { Considerable improvement of } \\
\text { financial performance }\end{array}$ & 0.595425 & 2.532824 \\
\hline
\end{tabular}

TABLE VI. CLOSENESS OF FACTORS TO PIS AND NIS AND FINAL RANKING OF PERFORMANCE OUTCOMES

\begin{tabular}{|c|c|c|c|}
\hline & Performance outcome & CL & Rank \\
\hline 1 & Growth of marketing processes & 0.491866 & 4 \\
\hline 2 & Attention to quality management & 0.328199 & 6 \\
\hline & Management commitment to quality standards & 0.346876 & 5 \\
\hline 4 & Attention to customer needs & 0.296987 & 7 \\
\hline 5 & Integration of processes (production and support) & 0.241283 & 9 \\
\hline 6 & Innovation in quality and design & 0.246606 & 8 \\
\hline 7 & Improvement of performance by innovation & 0.219554 & 10 \\
\hline 8 & Correct information sharing mechanism & 0.802182 & 3 \\
\hline 9 & $\begin{array}{c}\text { Superiority over competitors by value creation for } \\
\text { customers }\end{array}$ & 0.806944 & 2 \\
\hline 10 & Considerable improvement of financial & 0.809662 & 1 \\
\hline
\end{tabular}

D. Ranking of Knowledge Outcomes Using TOPSIS

Based on CL calculated for 7 knowledge outcomes, the top ranked factor was teamwork in most layers and the last factor 
was management encouragement for R\&D (Table VII and Table VIII).

TABLE VII. DISTANCE OF FACTORS FROM PIS AND NIS

\begin{tabular}{|c|c|c|c|}
\hline & Knowledge outcome & $\begin{array}{c}\text { Distance } \\
\text { from PIS }\end{array}$ & $\begin{array}{c}\text { Distance } \\
\text { from NIS }\end{array}$ \\
\hline 1 & Special attention to R\&D & 0.640068 & 1.22891 \\
\hline 2 & Allocation of budget to R\&D & 0.617216 & 1.250669 \\
\hline 3 & Teamwork in most layers & 0.543496 & 1.300591 \\
\hline 4 & $\begin{array}{c}\text { Classification of the knowledge obtained } \\
\text { from customer }\end{array}$ & 1.071552 & 0.827225 \\
\hline 5 & Management encouragement for R\&D & 1.184694 & 0.755773 \\
\hline 6 & Standardization of processing procedures & 1.131584 & 0.817202 \\
\hline 7 & $\begin{array}{c}\text { Employee participation in decision } \\
\text { making }\end{array}$ & 0.866669 & 0.996876 \\
\hline
\end{tabular}

TABLE VIII. CLOSENESS OF FACTORS TO PIS AND NIS AND FINAL RANKING OF KNOWLEDGE OUTCOMES

\begin{tabular}{|c|c|c|c|}
\hline & Knowledge outcome & CL & Rank \\
\hline 1 & Special attention to R\&D & 0.65753 & 3 \\
\hline 2 & Allocation of budget to R\&D & 0.669564 & 2 \\
\hline 3 & Teamwork in most layers & 0.705276 & 1 \\
\hline 4 & $\begin{array}{c}\text { Classification of the knowledge obtained from } \\
\text { customer }\end{array}$ & 0.435662 & 5 \\
\hline 5 & Management encouragement for R\&D & 0.38948 & 7 \\
\hline 6 & Standardization of processing procedures & 0.419339 & 6 \\
\hline 7 & Employee participation in decision making & 0.534935 & 4 \\
\hline
\end{tabular}

\section{E. Ranking of Human resource -Organization Outcomes} Using TOPSIS

Based on CL calculated for 5 human resource -organization outcomes, the top ranked factor was operational management training and the last factor was encouragement of creative and innovative employees (Table IX and Table X).

TABLE IX. DISTANCE OF FACTORS FROM PIS AND NIS

\begin{tabular}{|c|c|c|c|}
\hline & $\begin{array}{c}\text { Human resource -organization } \\
\text { outcomes }\end{array}$ & $\begin{array}{c}\text { Distance from } \\
\text { PIS }\end{array}$ & $\begin{array}{c}\text { Distance from } \\
\text { NIS }\end{array}$ \\
\hline 1 & $\begin{array}{c}\text { Facilitation of teamwork and } \\
\text { participation }\end{array}$ & 0.8540399 & 1.055667 \\
\hline 2 & Operational management training & 0.7263504 & 1.1967989 \\
\hline 3 & $\begin{array}{c}\text { Encouragement of creative and } \\
\text { innovative employees }\end{array}$ & 1.1407226 & 0.8260286 \\
\hline 4 & $\begin{array}{c}\text { Management awareness of } \\
\text { requirements and processes }\end{array}$ & 1.066389 & 0.8378727 \\
\hline 5 & $\begin{array}{c}\text { Employee encouragement for job } \\
\text { motivation }\end{array}$ & 0.8272775 & 1.1752109 \\
\hline
\end{tabular}

TABLE X. CLOSENESS OF FACTORS TO PIS AND NIS AND FINAL RANKING OF HUMAN RESOURCE -ORGANIZATION OUTCOMES

\begin{tabular}{|c|c|c|c|}
\hline & Human resource -organization outcome & CL & Rank \\
\hline 1 & Facilitation of teamwork and participation & 0.55279 & $\mathbf{3}$ \\
\hline 2 & Operational management training & 0.622312 & $\mathbf{1}$ \\
\hline 3 & $\begin{array}{c}\text { Encouragement of creative and innovative } \\
\text { employees }\end{array}$ & 0.419997 & $\mathbf{5}$ \\
\hline 4 & $\begin{array}{c}\text { Management awareness of requirements and } \\
\text { processes }\end{array}$ & 0.439999 & $\mathbf{4}$ \\
\hline 5 & Employee encouragement for job motivation & 0.586875 & $\mathbf{2}$ \\
\hline
\end{tabular}

\section{DisCUSSION}

One of the most important effects of knowledge management is its effect on organizational performance.
Knowledge management can influence organizational performance directly or indirectly; its effect is direct because knowledge is used for profitable products and indirect because knowledge management can be used for virtual leadership of the industry which can increase customer loyalty and acquire competitive advantage. The factors extracted from literature and semi-structured interviews with experts were reduced to 30 factors through 2 Delphi stages and confirmed as the most important outcomes of knowledge management in three groups of performance, knowledge and human resource -organization. Those 30 factors were included in a second questionnaire (32 questions) for running t-test. Results of t-test showed that 22 outcomes were more influenced than other 10 factors. These 22 outcomes include:

\section{A. Human resource -organization}

- Educational planning for operational managers.

- Continuous attention to knowledge workers.

- Facilitation of knowledge participation.

- Updated database of customer needs.

- Encouragement of creative personal for knowledge activities.

B. Knowledge

- Facilitation of organizational interactions for knowledge creation.

- Allocation of research budget.

- Development of R\&D based on market needs.

- Effective participation of employees in organizational decision making.

- Easy access to customer demands.

- Standardization of procedures.

- Motivational facilities for personnel to enrich knowledge resources.

C. Performance

- Increased financial performance.

- Competitive advantage in knowledge creation.

- Facilitated knowledge sharing within the organization.

- Growth of marketing processes.

- Management commitment to standards.

- Attention to quality management processes.

- Identification of customer needs.

- Growth of innovation and quality.

- Customer satisfaction.

- Integration of organizational processes.

\section{CONCLUSION}

According to the results, it can be concluded that the top ranked outcome of knowledge management implemented in the studied organization is knowledge, followed by human resource-organization and performance. Based on CL calculated for 10 performance outcomes, the top ranked factor was considerable improvement of financial performance and the last factor was improvement of performance by innovation. Based on CL calculated for 7 knowledge outcomes, the top ranked factor was teamwork in most layers and the last factor was management encouragement for R\&D. Based on CL calculated for 5 human resource-organization outcomes, the top 
ranked factor was operational management training and the last factor was encouragement of creative and innovative employees.

\section{REFERENCES}

[1] P. J. Hsieh, B. Lin, C. Lin, "The construction and application of knowledge navigator model $\left(\mathrm{KNM}^{\mathrm{TM}}\right)$ : An evaluation of knowledge management maturity", Expert Systems with Applications, Vol. 36, No. 2, pp. 4087-4100, 2009

[2] N. A kerman, "Knowledge-acquisition strategies and the effects on market knowledge-profiling the internationalizing firm", European Management Journal, Vol. 33, No. 2, pp. 79-88, 2015

[3] R. L. Priem, J. F. Butler, "Is the resource-based "view" a useful perspective for strategic management research?", Academy of Management Review, Vol. 26, No.1, pp. 22-40, 2001

[4] P. Wolf, "Balanced Evaluation: Monioring the "Success" of a Knowledge Management Project", FORUM: Qualitative Social Research, Vol. 11, No. 3, pp. 148-161, 2016

[5] J. Swan, S. Newell, H. Scarbrough, D. Hislop, "Knowledge management and innovation:Networks and networking", Journal of Knowledge Management, Vol. 3, No. 1, pp. 262-275, 1999

[6] W. W. Wu, Y. T. Lee, "Selecting knowledge management strategies by using the analytic network process", Expert Systems with Applications, Vol. 32, No. 3, pp. 841-847, 2007

[7] A. H. Gold, A. H. S. Arvind Malhotra, "Knowledge management: An organizational capabilities perspective", Journal of Management Information Systems, Vol. 18, No. 1, pp. 185-214, 2001

[8] K. S. Chin, K. C. Lo, J. P. Leung, "Development of user-satisfactionbased knowledge management performance measurement system with evidential reasoning approach", Expert Systems with Applications, Vol 37, No. 1, pp. 366-382, 2010

[9] Y. F. Wen, "An effectiveness measurement model for knowledge management", Knowledge-based Systems, Vol. 22, No. 5, pp. 363-367, 2009

[10] S. M. Tseng, "Knowledge management system performance measure index", Expert Systems with Applications, Vol. 34, No. 1, pp. 734-745, 2008

[11] I. Nonaka, H. Takeuchi, The knowledge-creating company: How Japanese companies create the dynamics of innovation, Oxford University Press, 1995

[12] R. D. Smith, A. S. Bollinger, "Managing organizational knowledge as a strategic asset", Journal of Knowledge Management,Vol. 5, No. 1, pp. $8-18,2001$

[13] P. F. Drucker, Managing oneself. Harvard Business Review Press, 2008

[14] J. K. Leidecker, A. V. Bruno, "Identifying and Using Critical Success Factors", Long Range Planning, Vol. 17, No. 1, pp. 23-32, 1984

[15] F. Lindner, A. Wald, "Success factors of knowledge management in temporary organizations", International Journal of Project Management, Vol. 29, No. 7, pp. 877-888, 2011

[16] L. S. Huang, C. P. Lai, "Critical success factors for knowledge management implementation in life insurance enterprises", International Journal of Management and Marketing Research, Vol. 7, No. 2, pp. 7989,2014

[17] K. G. Smith, C. J. Collins, K. D. Clark, "Existing knowledge, knowledge creation capability, and the rate of new product introduction in hightechnology firms", Academy of Management Journal, Vol. 48, No. 2, pp. 346-357, 2005 